\title{
Pharmaceutical Care for hypertensive patients provided within the Family Health Strategy in Goiânia, Goiás, Brazil
}

\author{
Bárbara Posse Reis Martins ${ }^{1, *}$, Aline Teixeira de Aquino, Mércia Pandolfo Provin², \\ Dione Marçal Lima², Nathalie de Lourdes Souza Dewulf², Rita Goreti Amaral² \\ ${ }^{1}$ Postgraduate Program in Health Sciences, School of Medicine, Federal University of Goiás, Goiânia, GO, Brazil, \\ ${ }^{2}$ School of Pharmacy, Federal University of Goiás, Goiânia, GO, Brazil
}

\begin{abstract}
The aim of Pharmaceutical Care programs is to improve patients' quality of life, and such programs are particularly effective in the case of chronic diseases such as hypertension. The objective of this longitudinal study was to analyze a Pharmaceutical Care model for hypertensive patients receiving care within the Family Health Strategy (FHS). All patients were being seen by an FHS team affiliated to a primary healthcare unit in Goiânia, Goiás, Brazil. Fourteen patients participated in the study, with each patient receiving six home visits during the Pharmaceutical Care. Overall, 142 drug-related problems were reported, the most common concerning the ineffectiveness of treatment (33.8\%). A total of 135 pharmaceutical interventions were performed, $92.6 \%$ of which involved pharmacist-patient communication, with $48.8 \%$ of these interventions being implemented. Cardiovascular risk decreased in three patients and remained unchanged in nine. In hypertensive patients with diabetes, fasting glucose levels were reduced in six out of nine cases. The Pharmaceutical Care model proposed here was effective in detecting drug-related problems and in proposing interventions to resolve or prevent these problems. Consequently, this may have contributed towards improving clinical parameters, such as fasting glucose levels and cardiovascular risk in hypertensive patients receiving care within the FHS.
\end{abstract}

Uniterms: Pharmaceutical care. Hypertension. Primary health care.

\begin{abstract}
A Atenção Farmacêutica tem como objetivo conseguir resultados concretos que melhorem a qualidade de vida do paciente, contribuindo especialmente em doenças crônicas, como a Hipertensão Arterial. O objetivo deste estudo foi analisar um modelo de Atenção Farmacêutica a pacientes com Hipertensão Arterial assistidos pela Estratégia Saúde da Família (ESF). Trata-se de um estudo longitudinal realizado com pacientes assistidos pela ESF de uma Unidade Básica de Saúde de Goiânia-GO. Participaram do estudo, 14 pacientes que receberam seis visitas domiciliares para Atenção Farmacêutica. Registraramse 142 Problemas Relacionados a Medicamentos (PRM) sendo mais frequente a falta de efetividade do tratamento (33,8\%). Realizaram-se 135 intervenções farmacêuticas, das quais 92,6\% foram com a comunicação farmacêutico-paciente, em que $48,8 \%$ das intervenções foram implementadas. Observou-se redução do risco cardiovascular em três pacientes e nove pacientes não apresentaram alteração no nível de risco cardiovascular. Entre os pacientes hipertensos e diabéticos observou-se redução da glicemia de jejum em seis. O modelo de Atenção Farmacêutica proposto foi capaz de detectar PRM propondo intervenções para resolvê-los e preveni-los e, consequentemente, pode ter contribuído na melhora de parâmetros clínicos como glicemia de jejum e risco cardiovascular em pacientes hipertensos assistidos pela ESF.
\end{abstract}

Unitermos: Atenção farmacêutica. Hipertensão arterial. Atenção primária à saúde.

\footnotetext{
*Correspondence: B. P. R. Martins. Faculdade de Medicina, Universidade Federal de Goiás. GO 403 Km 08 Via Senador Canedo, 74.735-600 - Goiânia - GO, Brasil. E-mail: barbaraposse@yahoo.com.br
} 


\section{INTRODUCTION}

The healthcare model proposed by the Brazilian National Health Service (SUS) promotes the universality of healthcare coverage and the integrality of healthcare, and endorses primary healthcare as a port of entry into the healthcare system (Cohn, 2008).

With integrality, Pharmaceutical Care becomes one of the components of the care process within the SUS, consisting of a set of actions aimed at providing access to and guaranteeing the rational use of drugs, with the practice of Pharmaceutical Care being inherent to these actions (Brasil, 2004).

Pharmaceutical Care is a professional practice in which the pharmacist assumes responsibility for the patient's requirements regarding pharmacotherapy. It is consistent with the proposal of primary healthcare and may be defined as the responsible provision of pharmacotherapy for the purpose of achieving concrete results that improve the patient's quality of life (Hepler, Strand, 1990). In fact, Pharmaceutical Care promotes adherence with the prescribed pharmacotherapy in a systematic, continuous and well-documented manner through the establishment of a pharmacist-patient relationship. The objective is to identify, resolve or prevent any drug-related problem that could interfere with the ultimate purpose of attaining satisfactory results through treatment (Cipolle et al., 2006).

In primary healthcare, pharmaceutical interventions may effectively prevent drug-related hospitalizations (Royal et al., 2006). Nevertheless, in the primary healthcare network of the SUS, Pharmaceutical Care focuses on management and drug dispensing processes; hence the pharmacist is kept at a distance from the patient and from the healthcare team (Araújo et al., 2008; Foppa et al., 2008).

Ricieri et al. (2006) believe that current policies in Brazil regarding drugs and Pharmaceutical Assistance do not encourage the pharmacist to act within the scope of primary healthcare, particularly in the case of the Family Health Strategy (FHS) initiative where there is no standard reference for pharmaceutical services, with experiences in this area being incipient and poorly propagated. Nevertheless, some studies have reported positive results regarding the inclusion and professional contribution of pharmacists in family healthcare teams (Loch-Neckel, Crepaldi, 2009; Provin et al., 2010).

The intent of the FHS is to reorganize and redefine the current healthcare model based on a broadened concept of the health-disease process. The essence of the FHS initiative lies in the fact that it actively seeks to implement health interventions in the target population rather than waiting for demand, with a focus on implementing healthrelated actions not only at an individual level but also within the individual's family and the environment in which he/she lives. This is achieved principally through preventive actions, by integrating healthcare professionals into the community (Viana, Dal Poz, 2005).

The chronic diseases have a major impact on morbidity and mortality of patients and represent a challenge for healthcare services. Patients with chronic diseases such as hypertension may benefit from preventive strategies to detect and treat complications at an early stage, thus reducing morbidity and mortality and consequently, health-related costs (Ministério da Saúde, 2011). A recent study conducted in Goiás between 2000 and 2008 showed that $17.2 \%$ of hospitalizations occurred as a result of cardiovascular conditions that could have been resolved at primary level (Batista et al., 2012). Therefore, Pharmaceutical Care may represent an important tool within the FHS, benefitting patients with hypertension by controlling their blood pressure (Castro et al., 2006; Lyra Júnior et al., 2008; Morgado et al., 2011; Obreli-Neto et al., 2011, Aguiar et al., 2012b), improving adherence to antihypertensive drugs (Souza et al., 2007; Aguiar et al., 2012b) and optimizing metabolic control of carbohydrates and lipids (Kicklighter et al., 2006; Correr et al., 2011; Obreli-Neto et al., 2011).

There is a need for further studies to be carried out in this area, particularly within the FHS. The objective of the present study was to analyze a Pharmaceutical Care model for hypertensive patients within the FHS in a primary healthcare unit in Goiânia, Goiás, Brazil.

\section{MATERIAL AND METHODS}

The present study was approved by the Research Ethics Committee of the Federal University of Goiás, under protocol number 120/2007. This longitudinal study was conducted with hypertensive patients receiving care within the FHS at a primary healthcare unit in the northern health district of the municipality of Goiânia, Goiás, between September 2010 and February 2012.

This healthcare unit operates with four family healthcare teams with each team comprising a doctor, a nurse, a dentist, a nursing technician and six community health agents. It was selected because it is the only unit in the municipality that has developed a Pharmaceutical Care program.

The inclusion criteria for this study consisted of hypertensive patients living within the catchment area of the healthcare unit, who had been referred for 
Pharmaceutical Care by the FHS teams and who had a history of difficult-to-control hypertension. In addition, the patients had to exhibit at least two of the following requisites adapted from those defined by Koecheler et al. (1989): blood pressure $\geq 140 \times 90 \mathrm{mmHg}$; in use of at least three drugs; therapeutic regimen changed at least twice in the previous year; presence of comorbidities and a history of non-compliance either reported by the patient or observed by the investigators. A total of 22 patients who fulfilled these criteria were included; however, there were subsequently eight losses, due to loss of contact with four patients, two patients that did not complete the sixth visit and two patients who died. Thus, only 14 patients concluded the study.

Exclusion criteria consisted of patients under 30 or over 74 years of age and all subjects who did not fulfill the aforementioned inclusion criteria.

Six home visits lasting approximately one hour each were scheduled, with a mean interval of 30 days between visits. The visits were made by two pharmacists, who had been previously trained in data collection and Pharmaceutical Care in accordance with an adapted version of the Pharmacist's Workup of Drug Therapy (PWDT) (Cipolle et al., 2006).

The PWDT method consists of clinical reasoning on the part of pharmacists caring for a patient through the establishment of a therapeutic pharmacist/patient relationship. According to this process, Pharmaceutical Care consists of three stages: 1) Analyzing the patient's condition in relation to their pharmacotherapeutic needs; 2) Planning the patient's care or follow-up; and 3) Evaluating the results of follow-up (Cipolle et al., 2006).

The variables evaluated in the study included sociodemographic data, smoking habits, presence of diabetes mellitus, fasting glucose level, comorbidities, systolic and diastolic blood pressure, dyslipidemias, total cholesterol and fractions, cardiovascular risk, the number of drugs used, antihypertensives used, drug-related problems, adherence to antihypertensive pharmacotherapy and pharmaceutical interventions.

Questionnaires were applied to patients for the purpose of collecting sociodemographic data and information on smoking habits, the presence of diabetes mellitus and comorbidities. Patients who smoked were considered smokers irrespective of the number of cigarettes they smoked per day.

Blood pressure levels were determined at each home visit by indirect auscultation using a calibrated aneroid sphygmomanometer and a clinical stethoscope in accordance with the measurement procedures proposed in the VI Brazilian Guidelines on Hypertension
(Sociedade Brasileira de Cardiologia, 2010). At each visit, two measurements were made, the first of which was disregarded.

The classification proposed by the IV Brazilian Guidelines on Dyslipidemias and the Prevention of Atherosclerosis (Sposito et al., 2007) was used to identify dyslipidemias, with total cholesterol, low-density lipoprotein (LDL) cholesterol, high-density lipoprotein (HDL) cholesterol and triglyceride levels being measured at the first and sixth visits, at which times fasting glucose was also determined.

Cardiovascular risk was evaluated in accordance with the Framingham risk score, which indicates the overall probability of cardiovascular disease for a 10 year period. The Framingham risk score calculation was adapted and endorsed by the Brazilian Ministry of Health and takes age, gender, LDL and HDL cholesterol, smoking, diabetes mellitus and blood pressure into consideration (Ministério da Saúde, 2006).

Each patient's medical prescriptions were evaluated to obtain information on the number of drugs and the classes of antihypertensives used.

Drug-related problems were identified by evaluating pharmacotherapy at each home visit. Problems were then classified in accordance with the definitions of Cipolle et al. (2006) into: 1) Indication (this refers to a need for additional medication or the use of unnecessary medication); 2) Effectiveness (this refers to the use of an inappropriately low dosage of a drug or use of an inappropriate drug); 3) Safety (this refers to the use of an inappropriately high dosage of a drug or to an adverse reaction to a drug); and 4) Adherence (this refers to nonadherence to treatment).

Adherence to antihypertensive pharmacotherapy was determined by applying the questionnaire developed by Morisky, Green and Levine, and validated by Bloch et al. (2008): 1) Do you ever forget to take your medicine?; 2) Are you careless at times about taking your medicine?; 3) When you feel better do you sometimes stop taking your medicine?; 4) Sometimes if you feel worse when you take the medicine, do you stop taking it?. Individuals who answered "no" to all these questions were considered adherent.

Pharmaceutical interventions are part of the process involved in monitoring pharmacotherapy and consist of planned and documented acts carried out with the patient and the healthcare professional (Ivama et al., 2002) to prevent or resolve drug-related problems and to achieve the established therapeutic objectives (Cipolle et al., 2006). Whenever necessary, these were carried out during the monitoring of pharmacotherapy and directed at the 
patient and/or FHS team and classified in accordance with the objective of each intervention as pharmacological or non-pharmacological interventions. The pharmacological interventions were subdivided into those carried out for the purpose of optimizing treatment and those carried out for the purpose of prevention.

The type of communication used in the interventions was classified as pharmacist-patient or pharmacistphysician. The outcome of each intervention was classified as: implemented (when there was agreement and the proposed management approach was carried out) or nonimplemented (when there was no agreement or when there was agreement but the proposed management approach was not carried out by the end of the study due to some difficulty).

The Statistical Software Package (SPSS ${ }^{\circledR}$ ), version 17.0, was used for data analysis. The KolmogorovSmirnov test was used to verify the normality of the sample. Absolute and relative frequencies, means and standard deviations were calculated. Fisher's exact test was used to evaluate the correlation between the interventions and the clinical results. Confidence level was defined as $95 \%$, with p-values $<0.05$ being considered statistically significant.

The categories defined in the calculation of the Framingham risk score were used to compare changes in systolic and diastolic blood pressure levels and in LDL cholesterol (Ministério da Saúde, 2006).

To compare changes in fasting glucose levels, the following classifications were used: $\leq 110 \mathrm{mg} / \mathrm{dL}$, $110-150 \mathrm{mg} / \mathrm{dL}, 151-270 \mathrm{mg} / \mathrm{dL}$ and $>270 \mathrm{mg} / \mathrm{dL}$, as defined in the Brazilian Guidelines for the Treatment and Monitoring of Diabetes Mellitus (Sociedade Brasileira de Diabetes, 2007).

\section{RESULTS}

Fourteen patients, 12 women $(85.7 \%)$ and 2 men $(14.3 \%)$, participated in the study. The mean age of these patients was 61.6 years. Table I shows the sociodemographic and clinical characteristics of the patients at baseline.

Overall, 142 drug-related problems were identified, a mean of 10.1 (standard deviation=5.6) per patient, with all patients experiencing at least three drug-related problems. Ineffectiveness of the treatment was the most common drug-related problem (33.8\%), followed by problems with indication (24.6\%), safety (23.2\%) and adherence (18.3\%). Non-adherence to pharmacotherapy was the least common of the drug-related problems; nevertheless, analysis of each individual patient showed that nine patients had
TABLE I - Sociodemographic and baseline clinical characteristics of hypertensive patients receiving Pharmaceutical Care within the Family Health Strategy

\begin{tabular}{lc}
\hline Characteristic & $\mathrm{n}(\%)$ \\
\hline Age group (years) & $1(7.1)$ \\
$\quad 45-54$ & $7(50)$ \\
$55-64$ & $6(42.9)$ \\
$\quad 65-74$ & \\
Educational level & $2(14.3)$ \\
$\quad$ Illiterate & $6(42.9)$ \\
$\quad$ Primary school & $5(35.7)$ \\
$\quad$ High school & $1(7.1)$ \\
$\quad$ University & \\
Monthly family income & $2(14.3)$ \\
$\quad \leq 1$ minimum salary & $8(57.1)$ \\
1-3 minimum salaries & $4(28.6)$ \\
$\quad>3$ minimum salaries & \\
Risk factors & $9(64.3)$ \\
$\quad$ Diabetes mellitus & $12(85.7)$ \\
Dyslipidemia & $1(7.1)$ \\
Smoking & $10(71.4)$ \\
Presence of at least 3 comorbidities & $7.6(2.14)$ \\
Number of drugs, mean (standard deviation) & \\
Adherence to hypertension pharmacotherapy & \\
$\quad$ Non-adherence & $7(50)$ \\
$\quad$ Adherence & \\
\hline & \\
& \\
&
\end{tabular}

this type of drug-related problem, with non-adherence to hypertensive medication involved in seven of these cases (Table I). At study endpoint, no change was found in patients' adherence to antihypertensive pharmacotherapy.

A total of 135 pharmaceutical interventions were carried out. The most common interventions were performed with the intention of optimizing treatment (45.9\%), particularly those involving pharmacist-patient communication $(90.3 \%)$ ). Overall, $48.8 \%$ of interventions $(n=66)$ were implemented, while $51.2 \%(n=69)$ were not. The interventions that proved most difficult to implement were the pharmacological interventions aimed at optimizing treatment as well as the non-pharmacological interventions (Table II).

Table III shows the principal classes of antihypertensive drugs and the therapeutic regimens used to control hypertension in these patients. More than half the patients were found to be in use of a combination of three or more antihypertensive agents, with diuretics, 
TABLE II - Description of the pharmaceutical interventions carried out during the study

\begin{tabular}{|c|c|c|c|c|c|}
\hline \multirow[b]{2}{*}{ Category of intervention } & \multirow{2}{*}{$\begin{array}{l}\text { Intervention } \\
\text { carried out }\end{array}$} & \multicolumn{2}{|c|}{ Type of Communication } & \multirow{2}{*}{$\begin{array}{l}\text { Not } \\
\text { implemented }\end{array}$} & \multirow[b]{2}{*}{ Implemented } \\
\hline & & $\begin{array}{l}\text { Pharmacist- } \\
\text { Patient }\end{array}$ & $\begin{array}{l}\text { Pharmacist- } \\
\text { Physician }\end{array}$ & & \\
\hline $\begin{array}{l}\text { Pharmacological intervention aimed at } \\
\text { optimizing treatment }\end{array}$ & $62(45.9 \%)$ & $56(90.3 \%)$ & $6(9.7 \%)$ & $35(56.5 \%)$ & $27(43.5 \%)$ \\
\hline To recommend method of administration & 15 & 15 & 0 & 6 & 9 \\
\hline To improve adherence with treatment & 24 & 24 & 0 & 11 & 13 \\
\hline To initiate treatment & 9 & 8 & 1 & 8 & 1 \\
\hline To review pharmacotherapy & 13 & 8 & 5 & 9 & 4 \\
\hline To prevent drug interaction & 1 & 1 & 0 & 1 & 0 \\
\hline Preventive pharmacological intervention & $31(23 \%)$ & $29(93.5 \%)$ & $2(6.5 \%)$ & $8(25.8 \%)$ & $23(74.2 \%)$ \\
\hline To confirm medical prescription & 2 & 1 & 1 & 0 & 2 \\
\hline To prevent adverse reactions & 13 & 13 & 0 & 4 & 9 \\
\hline To recommend monitoring & 10 & 10 & 0 & 2 & 8 \\
\hline To discontinue medication & 3 & 2 & 1 & 1 & 2 \\
\hline To initiate treatment & 3 & 3 & 0 & 1 & 2 \\
\hline Non pharmacological Intervention & $42(31.1 \%)$ & $40(95.2 \%)$ & $2(4.8 \%)$ & $26(62 \%)$ & $16(38 \%)$ \\
\hline To provide counseling on lifestyle changes & 31 & 31 & 0 & 16 & 15 \\
\hline To refer patient to another professional & 8 & 6 & 2 & 8 & 0 \\
\hline To provide counseling on diabetic foot care & 2 & 2 & 0 & 1 & 1 \\
\hline $\begin{array}{l}\text { To provide counseling on the use of } \\
\text { compression stockings }\end{array}$ & 1 & 1 & 0 & 1 & 0 \\
\hline$\overline{\text { Total }}$ & $135(100 \%)$ & $125(92.6 \%)$ & $10(7.4 \%)$ & $69(51.2 \%)$ & $66(48.8 \%)$ \\
\hline
\end{tabular}

TABLE III - Use of antihypertensive drugs by hypertensive patients receiving care within the Family Health Strategy

\begin{tabular}{lcc}
\hline Use of drugs & $1^{\text {st }}$ Visit n (\%) & $6^{\text {th }}$ Visit n (\%) \\
\hline Therapeutic regimen & & \\
$\quad$ Monotherapy & $2(14.3)$ & $2(14.3)$ \\
Combination of two therapeutic classes & $3(21.4)$ & $4(28.6)$ \\
$\quad$ Combination of three or more therapeutic classes & $9(64.3)$ & $8(57.1)$ \\
Classes of antihypertensive drug & & \\
Diuretics & $10(71.4)$ & $9(64.3)$ \\
Angiotensin-converting enzyme inhibitors & $9(64.3)$ & $8(57.1)$ \\
Calcium channel blockers & $8(57.1)$ & $8(57.1)$ \\
Beta-blockers & $7(50)$ & $7(50)$ \\
Angiotensin II receptor blockers & $4(28.6)$ & $4(28.6)$ \\
Alpha-blockers & $3(21.4)$ & $3(21.4)$ \\
\hline
\end{tabular}

angiotensin-converting enzyme inhibitors and calcium channel blockers being the most common. As shown in Table II, 13 pharmaceutical interventions were performed in which there was a suggestion that pharmacotherapy should be reviewed; however, as shown in Table III, changes in therapeutic regimens were made in only two cases during follow-up.

Table IV compares the clinical parameters of these patients at the first and sixth visits. As shown, an improvement was found on at least one parameter in 
TABLE IV - Changes in the clinical parameters of hypertensive patients receiving care within the Family Health Strategy

\begin{tabular}{lccccc}
\hline Change & $\begin{array}{c}\text { Systolic blood } \\
\text { pressure }\end{array}$ & $\begin{array}{c}\text { Diastolic blood } \\
\text { pressure }\end{array}$ & $\begin{array}{c}\text { Cardiovascular } \\
\text { risk }\end{array}$ & $\begin{array}{c}\text { LDL } \\
\text { cholesterol }\end{array}$ & $\begin{array}{c}\text { Fasting } \\
\text { glucose }\end{array}$ \\
\hline Improvement & $3(21.4 \%)$ & $2(14.3 \%)$ & $3(21.4 \%)$ & $3(21.4 \%)$ & $6(66.7 \%)$ \\
Unchanged & $6(42.9 \%)$ & $10(71.4 \%)$ & $9(64.3 \%)$ & $6(42.9 \%)$ & $1(11.1 \%)$ \\
Worsening & $5(35.7 \%)$ & $2(14.3 \%)$ & $1(7.1 \%)$ & $4(28.6 \%)$ & $2(22.2 \%)$ \\
\hline
\end{tabular}

12 cases. Cardiovascular risk level decreased in three patients, remained unaltered in nine and increased in one patient. In the remaining patient, cardiovascular risk could not be calculated due to missing data.

Fasting glucose, shown only for patients who had both hypertension and diabetes mellitus, was the parameter that proved most sensitive to change. Of the nine patients with hypertension and diabetes mellitus, glucose levels decreased in six cases (Table IV).

No correlation was found between the type of intervention implemented and systolic or diastolic blood pressure, cardiovascular risk, LDL cholesterol or fasting glucose levels (non-pharmacological interventions $\mathrm{p}=0.625 ; 0.500 ; 0.318 ; 0.571 ; 0.536$; pharmacological interventions aimed at optimizing treatment $\mathrm{p}=0.625$; $0.500 ; 0.530 ; 0.536 ; 0.250$; and those aimed at prevention $\mathrm{p}=0.357 ; 1.00 ; 0.530 ; 0.571 ; 0.750)$. Nevertheless, all six patients whose glucose levels improved had been submitted to at least one pharmacological intervention aimed at optimizing treatment.

\section{DISCUSSION}

The results of this study showed that drug-related problems were common in these hypertensive patients where this may be related to the considerable number of drugs that many participants were taking (polypharmacy). In this study, the mean number of drug-related problems per patient was higher than that reported in the studies conducted by Lyra Júnior et al. (2008) and Castro et al. (2006). The most common drug-related problem concerned the ineffectiveness of pharmacotherapy and this finding is in agreement with the studies conducted by Castro et al. (2006) and Provin et al. (2010).

As a consequence of the high number of drug-related problems, a substantial number of interventions were performed, most of which involved pharmacist-patient communication. These findings are consistent with the results of a study conducted by Romano-Lieber et al. (2002) in which $70 \%$ of the interventions were carried out with the patient, principally in the form of educational actions and counseling with respect to the therapeutic regimen.
Family members were often present during the pharmaceutical intervention, a fact that may have influenced patients' conduct and decisions regarding the interventions. Studies have shown that in primary healthcare, the ability of the healthcare professional to communicate and intervene, with a focus that also includes the patient's family, contributes towards the success of the actions (Wagner et al., 2004; Foppa et al., 2008).

In general, the rate of implementation of the interventions was poor. The interventions that proved the most difficult to implement were those pharmacological interventions aimed at optimizing treatment, either by proposing the initiation of treatment or reviewing pharmacotherapy, and also non-pharmacological interventions that referred the patient to another healthcare professional, thus making evaluation of the results impossible. This may have been due to the fact that these actions depended on being able to schedule medical consultations with specialists or other professionals and also on the availability of certain services within the public healthcare system.

Another factor that may have contributed to the inability to implement the interventions was the fact that few interventions were performed directly with the attending physician. This may have been due to a difficulty in communication between the investigating pharmacists and the physicians in the attending teams, rendering the discussion of cases difficult. This finding corroborates the results reported by Triller and Hamilton (2007) and Provin et al. (2010), who also conducted Pharmaceutical Care in home visits and believe that the lack of communication between pharmacist and prescriber leads to poor interventions being implemented.

The work of a multi-professional team is fundamental in ensuring integrated healthcare within the Family Health Strategy, since it permits different forms of dealing with the patient and their family within the intervention process, facilitating the exchange of information between the professionals in the team with the aim of optimizing results and establishing better interaction between the team and the community (Oliveira, Spiri, 2006). 
Adequate control of hypertension depends on behavioral changes such as adopting a healthy diet, practicing physical exercise regularly and cessation of smoking (Santos, Abreu-Lima, 2009). Nevertheless, interventions involving patient counseling, aimed at improving adherence and at implementing lifestyle changes, are the most difficult to put into effect, suggesting that achieving behavioral changes represents a challenge. According to Oliveira et al. (2009), changing life habits is a difficult task and leads to dissatisfaction in hypertensive patients, principally with respect to sustaining these new habits.

Such resistance may also have contributed to the absence of any significant changes in blood pressure control and, consequently, in patients' cardiovascular risk level, although cardiovascular risk was found to decrease in some patients studied. Santschi et al. (2011) stressed the importance of interventions performed by pharmacists alone, or in conjunction with other professionals, in identifying and controlling the risk factors for cardiovascular disease.

Around half the interventions were performed to optimize pharmacological treatment in an integrated manner, not simply focusing on hypertension but also on the patient's other health issues such as diabetes mellitus. This strategy is in line with the care provided within the Family Health Strategy, which has the integrality of care as one of its goals (Viana, Dal Poz, 2005). This may have collaborated towards the reduction in glucose levels experienced by the majority of patients with both hypertension and diabetes. Other studies have reported a significant reduction in glucose levels in diabetic patients receiving Pharmaceutical Care (Borges et al., 2010; Correr et al., 2011).

Diuretics and angiotensin-converting enzyme inhibitors were the most commonly prescribed classes of antihypertensives, a finding that mirrors the results reported by Vosgerau et al. (2011), who analyzed the use of antihypertensives in a family healthcare unit in the south of Brazil. This finding reinforces the fact that diuretics and angiotensin-converting enzyme inhibitors are the drugs of choice for the treatment of hypertension in view of the benefits conferred by the resultant reductions in blood pressure, cardiovascular events and mortality, as shown in the ALLHAT (2002) and HOPE (2000) studies.

The majority of the patients were found to be in concomitant use of at least three antihypertensive drugs, suggesting difficult-to-control hypertension, considering that the VI Brazilian Guidelines for Hypertension (Sociedade Brasileira de Cardiologia, 2010) recommend the combination of different classes of antihypertensive drugs when the patient is in the second or third stage of hypertension or in the first stage but with a high cardiovascular risk.

The majority of cases of non-adherence concerned antihypertensive pharmacotherapy. Around half the patients were adherent with therapy, a similar figure to that reported in the study conducted by Bloch et al. (2008). The poor educational level of the patients in the present study and the number of drugs used may have contributed towards this result, since other studies have reported poor adherence to be associated with educational level (Busnello et al., 2001; Araújo, Garcia, 2009), therapeutic regimen, and number of drugs prescribed (Leite, Vasconcelos, 2003). Furthermore, it may imply that further studies should be conducted to analyze the association between difficult-to-control hypertension, the time of treatment and patient adherence with pharmacotherapy, since these findings suggest the patient may become discouraged with the ineffectiveness of the therapy in controlling the disease.

Despite the 24 interventions aimed at optimizing adherence to treatment, adherence to antihypertensive pharmacotherapy remained unchanged at study endpoint. This finding contradicts the data reported by Chamorro et al. (2011), who also used the questionnaire developed by Morisky, Green and Levine but found an increase in adherence at the end of the study. Since sociocultural aspects as well as other factors are involved (Gusmão, Mion Jr., 2006), improving compliance remains a difficult task.

Few studies have been conducted on Pharmaceutical Care within the Family Health Strategy initiative, making it difficult to compare the findings of the present study with others reported in the literature. The majority of previous studies on Pharmaceutical Care in hypertensive patients were conducted in outpatient clinics and community pharmacies (Castro et al., 2006; Lyra Jr et al., 2008; Morgado et al., 2011; Aguiar et al., 2012a).

The aim of the healthcare model proposed by the Family Health Strategy is not limited to curative actions but deals principally with the prevention of diseases and disorders and with promoting health. Therefore, its interventions occur even before the individual is aware of any health issue (Viana, Dal Poz, 2005). It is hence possible that lack of perception of a health problem may have altered the way in which the individuals in this study perceived and understood the recommended measures. In contrast, patients seeking medical care at outpatient clinics or community pharmacies do so because of an emerging health necessity perceived by the individual, thus facilitating their compliance with the proposed interventions. 
Another characteristic of this particular study is the fact that home visits were made by a professional pharmacist for the purpose of providing Pharmaceutical Care. Home visits are understood to represent a useful technique of interaction in family healthcare (Sakata et al., 2007), since they provide a diversity of complementary information obtained by being able to observe the patient in their home environment and family relationships (Sakata et al., 2007; Albuquerque, Bosi, 2009). However, the present study has certain limitations. In some cases conversation between the pharmacist and the patient proved difficult, since the patient's attention was diverted to domestic chores and family members, among other factors that can affect communication.

Furthermore, the frequency and regularity of these visits should be established with caution in order to prevent the patients from becoming discouraged or complacent. Mandú et al. (2008) saw it as a challenge to balance the benefits and values of home visits within the Family Health Strategy initiative against the dependency and complacency of users with respect to their health problems.

In conclusion, the results of the present study showed that Pharmaceutical Care is capable of detecting drug-related problems and of proposing interventions to resolve or prevent these problems. As a result, this may contribute towards improving clinical parameters such as fasting glucose levels and cardiovascular risk in hypertensive patients receiving care within the Family Health Strategy initiative.

Nevertheless, further studies, including an economic assessment, need to be conducted within the Family Health Strategy initiative to demonstrate the effectiveness of Pharmaceutical Care for controlling blood pressure and reducing cardiovascular risk. The results of such studies may provide support for actions to implement Pharmaceutical Care programs that would have a positive effect on healthcare and prevent complications in patients with chronic diseases, particularly those with hypertension.

\section{ACKNOWLEDGEMENTS}

The authors are grateful to the Goiás Foundation for Research Support (FAPEG) for the financial support provided (reference 01/2007) and to the Coordination for the Improvement of Higher Education Personnel (CAPES) for providing the investigators with master's fellowships.

\section{REFERENCES}

AGUIAR, P.M.; BALISA-ROCHA, B.J.; BRITO, G.C.; DA SILVA.; W.B. MACHADO, M.; LYRA Jr., D.P. Pharmaceutical care in hypertensive patients: a systematic literature review. Res. Social Adm. Pharm., v.8, n.5, p.383396, 2012a.

AGUIAR, P.M.; BALISA-ROCHA, B.J.; BRITO, G.C.; LYRA Jr., D.P. Pharmaceutical care program for elderly patients with uncontrolled hypertension. J. Am. Pharm. Assoc., v.52, n. 4, p. 515-518, 2012 b.

ALBUQUERQUE, A.B.B.D.; BOSI, M.L.M. Visita domiciliar no âmbito da estratégia saúde da família: percepções de usuários no município de Fortaleza, Ceará, Brasil. Cad. Saúde Pública, v.25, n.5, p.1103-1112, 2009.

ALLHAT Officers and Coordinators for the ALLHAT Collaborative Research Group. Major outcomes in high-risk hypertensive patients randomized to angiotensin-converting enzyme inhibitor or calcium channel blocker vs diuretic: the Antihypertensive and Lipid-Lowering Treatment to Prevent Heart Attack Trial (ALLHAT). JAMA, v.288, n.23, p.2981, 2002.

ARAÚJO, A.L.A.; PEREIRA, L.R.L.; UETA, J.M.; FREITAS, O. Perfil da assistência farmacêutica na atenção primária do Sistema Único de Saúde. Ciênc. Saúde Coletiva, v.3, suppl.1, p.611-617, 2008.

ARAÚJO, G.B.S.; GARCIA, T.R. Adesão ao tratamento antihipertensivo: uma análise conceitual. Rev. Eletr. Enf., v.8, n.2, p.259-272, 2009.

BATISTA, S.R.R.; JARDIM, P.C.B.V.; SOUSA, A.L.L.; SALGADO, C.M. Hospitalizations due to primary caresensitive cardiovascular conditions in municipalities of Central-West Brazil. Rev. Saúde Pública, v.46, n.1, p.3442, 2012.

BLOCH, K.V.; MELO, A.N.D.; NOGUEIRA, A.R. Prevalência da adesão ao tratamento anti-hipertensivo em hipertensos resistentes e validação de três métodos indiretos de avaliação da adesão. Cad. Saúde Pública, v.24, n.12, p.2979-2984, 2008.

BORGES, A.P.; GUIDONI, C.M.; FERREIRA, L.D.; DE FREITAS, O.; PEREIRA, L.R. The pharmaceutical care of patients with type 2 diabetes mellitus. Pharm. World Sci., v.32, p.730-736, 2010. 
BRASIL. Conselho Nacional de Saúde. Resolução. n.338 de 06 maio 2004. Available at: 2012 October 15. Accessed on: http://portal.saude.gov.br/portal/arquivos/pdf/resol_cns338. pdf.

BUSNELLO, R.G.; MELCHIOR, R.; FACCIN, C.; VETTORI, D.; PETTER, J.; MOREIRA, L.B.; FUCHS, F.D. Características associadas ao abandono do acompanhamento de pacientes hipertensos atendidos em um ambulatório de referência. Arq. Bras. Cardiol., v.76, p.349-351, 2001.

CASTRO, M.S.; FUCHS, F.D.; SANTOS, M.C.; MAXIMILIANO, P.; GUS, P.; MOREIRA, L.B.; FERREIRA, M.B.C. Pharmaceutical care program for patients with uncontrolled hypertension. Report of a double-blind clinical trial with ambulatory blood pressure monitoring. Am. J. Hypertens., v.19, n.5, p.528-533, 2006.

CHAMORRO, M.A.; GARCIA-JIMENEZ, E.; AMARILES, P.; CHAMORRO, A.R.; MERINO, E.M.P.; MARTINEZ, F.M.; DADER, M.J.F. Effect of pharmacist involvement in adherence to medications in patients with high to moderate cardiovascular risk (Study EMDADER-CVINCUMPLIMIENTO). Aten. Primaria, v.43, n.5, p.245$253,2011$.

CIPOLLE, R.J.; STRAND, L.M.; MORLEY, P.C. O exercício do cuidado farmacêutico. Brasília: Conselho Federal de Farmácia, 2006. 396 p.

COHN, A. A reforma sanitária brasileira: a vitória sobre o modelo neoliberal. Medicina Social, v.3, n.2, p.102-112, 2008.

CORRER, C.J.; MELCHIORS, A.C.; FERNANDEZ-LLIMOS, F.; PONTAROLO, R. Effects of a pharmacotherapy followup in community pharmacies on type 2 diabetes patients in Brazil. Int. J. Clin. Pharm., v.33, p.273-280, 2011.

FOPPA, A.A.; BEVILACQUA, G.; PINTO, L.H.; BLATT, C.R. Atenção farmacêutica no contexto da estratégia saúde da família. Braz. J. Pharm. Sci., v.44, n.4, p.727-737, 2008.

GUSMÃO, J.L.; MION Jr., D. Adesão ao tratamento-conceitos. Rev. Bras. Hipertens., v.13, n.1, p.23-25, 2006.

Heart Outcomes Prevention Evaluation (HOPE) Study Investigators. Effects of ramipril on cardiovascular and microvascular outcomes in people with diabetes mellitus: results of the HOPE study and MICRO-HOPE substudy. Lancet., v.355, p.253-259, 2000.
HEPLER, C.D.; STRAND, L.M. Opportunities and responsibilities in pharmaceutical care. Am. J. Health Syst. Pharm., v.47, p.533-543, 1990.

IVAMA, A.M.; NOBLAT, L.; CASTRO, M.S.; OLIVEIRA, N.V.B.V.; JARAMILLO, N.M.; RECH, N. Consenso Brasileiro de Atenção Farmacêutica: proposta. Brasília: Organização Pan-Americana de Saúde, 2002. 24 p.

KICKLIGHTER, C.E.; NELSON, K.M.; HUMPHRIES, T.L.; DELATE, T. Evaluación de una intervención de farmacia clínica sobre el control de la presión arterial. Pharmacy Pract., v.4, n.3, p.110-116, 2006.

KOECHELER, J.A.; ABRAMOWITZ, P.W.; SWIM, S.E.; DANIELS, C.E. Indicators for the selection of ambulatory patients who warrant pharmacist monitoring. Am. J. Health Syst. Pharm., v.46, p.729-732, 1989.

LEITE, S.N.; VASCONCELLOS, M.P.C. Adesão à terapêutica medicamentosa: elementos para a discussão de conceitos e pressupostos adotados na literatura. Ciênc. Saúde Coletiva, v.8, n.3, p.775-782, 2003.

LOCH-NECKEL, G.; CREPALDI, M.A. Pharmacist contributions for basic care from the perspective of professionals of familial health care teams. Braz. J. Pharm. Sci., v.45, n.2, p.263-272, 2009.

LYRA Jr., D.P.; MARCELLINI, P.S.; PELÁ, I.R. Effect of pharmaceutical care intervention on blood pressure of elderly outpatients with hypertension. Braz. J. Pharm. Sci., v.44, n.3, p.451-457, 2008.

MANDÚ, E.N.T.; GAÍVA, M.A.M.; SILVA, M.D.A.; SILVA, A.M.N.D. Visita domiciliária sob o olhar de usuários do Programa Saúde da Família. Texto Contexto Enferm., v.17, n.1, p.131-140, 2008.

MINISTÉRIO DA SAÚDE. Secretaria de Atenção a Saúde. Departamento de Atenção Básica. Prevenção clínica de doença cardiovascular, cerebrovascular e renal crônica. Cadernos de Atenção Básica, n. 14, 2006.

MINISTÉRIO DA SAÚDE. Secretaria de Vigilância em Saúde. Departamento de Análise de Situação de Saúde. Plano de ações estratégicas para o enfrentamento das doenças crônicas não transmissíveis (DCNT) no Brasil 2011-2022. Brasília: Ministério da Saúde, 2011. 148 p. 
MORGADO, M.P.; MORGADO, S.R.; MENDES, L.C.; PEREIRA, L.J.; CASTELO-BRANCO, M. Pharmacist interventions to enhance blood pressure control and adherence to antihypertensive therapy: review and metaanalysis. Am. J. Health Syst. Pharm., v.68, p.241-253, 2011.

OBRELI-NETO, P.R.; MARUSIC, S.; LYRA Jr., D.P.; PILGER, D.; CRUCIOL-SOUZA, J.M.; GAETI, W.P.; CUMAN, R.K.N. Effect of a 36-month pharmaceutical care program on coronary heart disease risk in elderly diabetic and hypertensive patients. J. Pharm. Pharm. Sci., v.14, n.2, p.249-263, 2011.

OLIVEIRA, E.A.; TAMANINI, P.S.; SOUZA, P.L.; BULBACH, S.; GOMES, M.J. Autopercepção do estilo de vida em indivíduos com hipertensão arterial. Rev. Bras. Pesqui. Saúde, v.11, n.3, p.18-24, 2009.

OLIVEIRA, E.M.; SPIRI, W.C. Family Health Program: the experience of a multiprofessional team. Rev. Saúde Pública, v.40, n.4, p.1-7, 2006.

PROVIN, M.P.; CAMPOS, A.P.; NIELSON, S.E.O.; AMARAL, R.G. Atenção farmacêutica em Goiânia: inserção do farmacêutico na estratégia saúde da família. Saúde Soc., v.19, n.3, p.717-723, 2010.

RICIERI, M.C.; PREVIATTI, D.; CAMPESE, M.; CONSTANTINI, H.F.; MONTRUCCHIO, D.P.; KADES, A.S.O.; BUFFON, M.C.M.; FURMAN, I.M. O farmacêutico no contexto da Estratégia em Saúde da Família, que realidade é esta? Visão Acadêmica, v.7, n.2, p.55-62, 2006.

ROMANO-LIEBER, N.S.; TEIXEIRA, J.J.V.; FARHAT, F.C.L.G.; RIBEIRO, E. CROZATTI, M.T.L.; OLIVEIRA, G.S.A. Revisão dos estudos de intervenção do farmacêutico no uso de medicamentos por pacientes idosos. Cad. Saúde Pública, v.18, n.6, p.1499-1507, 2002.

ROYAL, S.; SMEATON, L.; AVERY, A.J.; HURWITZ, B.; SHEIKH, A. Interventions in primary care to reduce medication related adverse events and hospital admissions: systematic review and meta-analysis. Qual. Saf. Health Care, v.15, n.1, p.23-31, 2006.

SAKATA, K.N.; DE ALMEIDA, M.C.P.; ALVARENGA, A.M; CRACO, P. F.; BISTAFA-PEREIRA, M.J. Concepções da equipe de saúde da família sobre as visitas domiciliares. Rev. Bras. Enferm., v.60, n.6, p.659-664, 2007.
SANTOS, A.C.; ABREU-LIMA, C. Hipertensão de difícil controle: impacto do estilo de vida. Rev. Bras. Hipertens., v.16, suppl.1, p.S5-S6, 2009.

SANTSCHI, V.; CHIOLERO, A.; BURNAND, B.; COLOSIMO, A.L.; PARIDIS, G. Impact of pharmacist care in the management of cardiovascular disease risk factors: a systematic review and meta-analysis of randomized trials. Arch. Intern. Med., v.171, n.16, p.1441-1453, 2011.

SOCIEDADE BRASILEIRA DE CARDIOLOGIA. VI Diretrizes Brasileiras de Hipertensão. Arq. Bras. Cardiol., v.95, p.I-III, 2010.

SOCIEDADE BRASILEIRA DE DIABETES. Tratamento e acompanhamento do diabetes mellitus. Diretrizes da Sociedade Brasileira de Diabetes, 2007. 168 p.

SOUZA, W.A.; YUGAR-TOLEDO, J.C.; BERGSTENMENDES, G.; SABHA, M.; MORENO Jr., H. Effect of pharmaceutical care on blood pressure control and healthrelated quality of life in patients with resistant hypertension. Am. J. Health Syst. Pharm., v.64, n.18, p.1955-1961, 2007.

SPOSITO, A.C.; CARAMELLI, B.; FONSECA, F.A.H.; BERTOLAMI, M.C. IV diretriz brasileira sobre dislipidemias e prevenção da aterosclerose: departamento de aterosclerose da Sociedade Brasileira de Cardiologia. Arq. Bras. Cardiol., v.88, p.2-19, 2007.

TRILLER, D.M.; HAMILTON, R.A. Effect of pharmaceutical care services on outcomes for home care patients with heart failure. Am. J. Health Syst. Pharm., v.64, n.21, p.2244-2249, 2007.

VIANA, A.L.D.; DAL POZ, M.R. A reforma do Sistema de Saúde no Brasil e o Programa Saúde da Família. Physis: Rev. Saúde Coletiva, v.15, p.225-264, 2005.

VOSGERAU, M.Z.S.; CABRERA, M.A.S.; DE SOUZA, R.K.T. Saúde da família e utilização de medicamentos antiHipertensivos e antidiabéticos. Rev. Bras. Cardiol., v.24, n.2, p.95-104, 2011.

WAGNER, H.L.; WAGNER, A.B.P.; TALBOT, Y.R. Aplicação do pensamento sistêmico no trabalho em Saúde da Família. Rev. Bras. Med. Fam. Comunidade, v.1, n.1, p.29-35, 2004.

Received for publication on $09^{\text {th }}$ December 2012 Accepted for publication on $15^{\text {th }}$ May 2013 